\title{
Relation between endoleak development and aneurysm diameter in patients with abdominal aorta aneurysm treated with endovascular repair
}

\author{
Serkan Yazman, İsmail Yürekli, Ufuk Yetkin, Levent Yılık, Köksal Dönmez, Hasan İner, Tevfik Güneş, Barçın Özcem, \\ Ali Gürbüz
}

From World Society of Cardiothoracic Surgeons 25th Anniversary Congress, Edinburgh

Edinburgh, UK. 19-22 September 2015

\section{Background/Introduction}

Although it may differ with age, gender and body mass index; diameter of infrarenal aorta is between 1 and $2,5 \mathrm{~cm}$. Its mean value in male is $21,4 \mathrm{~mm}$ and $18,7 \mathrm{~mm}$ in female. More than $50 \%$ irreversible dilation of abdominal aorta is called abdominal aorta aneurysm. It is usually observed as dilation of aortic diameter over $3 \mathrm{~cm}$ between aortic bifurcation and renal artery.

\section{Aims/Objectives}

We retrospectively investigated and included elective or emergency (ruptured abdominal aortic aneurysm) intervention of 203 abdominal aortic aneurysm patients treated with endovascular aortic repair (EVAR) between dates January 2006 and January 2013. Sixteen of these patients were female $(7,9 \%)$ and 187 of them were male $(92,1 \%)$.

\section{Method}

In our study mean aneurysm diameter was $65,83 \mathrm{~mm} \pm$ 14,92 $\mathrm{mm}$ (between $40 \mathrm{~mm}$ and $130 \mathrm{~mm}$ ).

\section{Results}

When we compared endoleak and aneurysm diameter; mean diameter was $64,7 \pm 16,96 \mathrm{~mm}$ in endoleak group and $68,22 \pm 14,61 \mathrm{~mm}$ in group without endoleak. There was not any statistical significance.

\section{Discussion/Conclusion}

Intervention is indicated in patients with abdominal aorta aneurysm diameter over $5 \mathrm{~cm}$, symptomatic patients with

\footnotetext{
Department of Cardiovascular Surgery, Katip Celebi University Izmir Ataturk
} Training and Research Hospital, Izmir, Turkey aneurysm diameter less than $5 \mathrm{~cm}$, equal to or more than $5 \mathrm{~mm}$ dilation of aneurysm in six months, ruptured or prone to rupture aneurysms, saccular or dissected aneurysms.

\section{Consent}

Written informed consent was obtained from the patient for publication of this Case report and any accompanying images. A copy of the written consent is available for review by the Editor-in-Chief of this journal.

Published: 16 December 2015

doi:10.1186/1749-8090-10-S1-A224

Cite this article as: Yazman et al:: Relation between endoleak development and aneurysm diameter in patients with abdominal aorta aneurysm treated with endovascular repair. Journal of Cardiothoracic Surgery 2015 10(Suppl 1):A224.

Submit your next manuscript to BioMed Central and take full advantage of:

- Convenient online submission

- Thorough peer review

- No space constraints or color figure charges

- Immediate publication on acceptance

- Inclusion in PubMed, CAS, Scopus and Google Scholar

- Research which is freely available for redistribution

Submit your manuscript at www.biomedcentral.com/submit
() Biomed Central 